\title{
UPRAVLJANJE PROJEKTOM IZGRADNJE UREĐAJA ZA PROČIŠĆAVANJE OTPADNIH VODA U KNEŽEVIM VINOGRADIMA
}

\author{
Nenad Šonjić \\ Hidroing d.o.o. Osijek, mag.ing.aedif. \\ Zlata Dolaček-Alduk \\ Sveučilište Josipa Jurja Strossmayera u Osijeku, Građevinski fakultet Osijek, docent \\ Mirna Habuda-Stanić \\ Sveučilište Josipa Jurja Strossmayera u Osijeku, Prehrambeno-tehnološki fakultet Osijek, docent
}

Sažetak: U radu je prikazana struktura projekta izgradnje uređaja za pročišćavanje otpadnih komunalnih voda u Kneževim Vinogradima, kapaciteta $2500 \mathrm{ES}$, „SBR“ tehnologijom. Struktura projekta prikazana je kroz tri faze projekta: koncipiranje, definiranje i izvođenje, uz povezivanje vremena i troškova projekta.

Ključne riječi: struktura projekta izgradnje uređaja za pročišćavanje otpadnih voda, „SBR“ tehnologija pročišćavanja otpadnih voda

\section{PROJECT MENAGEMENT OF WASTE WATER TREATMENT PLANT IN THE KNEŽEVI VINOGRADI}

Abstract: This paper presents the architecture of the project construction of waste water treatment plant in Kneževi Vinogradi 2500 population equivalent by „SBR" purification technology principle. Architecture of the project is displayed through three stages: conception, defining and realization where are made link between timeline and project costs.

Key words: architecture of the project construction of waste water treatment plant, SBR Waste Water Treatment 


\section{Uvod}

U skladu sa Zakonom o vodama (NN 153/09) i Odlukom o proglašenju Zakona o potvrđivanju Konvencije o suradnji na zaštiti i održivoj uporabi rijeke Dunav (NN 2/96), poboljšanju uvjeta vodoopskrbe, odvodnje i zaštite od poplava u slivovima rijeka Save, Drave i Dunava, kao i s činjenicom da se veći dio otpadnih voda ispušta iz sustava prikupljanja i odvodnje otpadnih voda bez pročišćavanja u prirodne prijamnike, bila je nužna izgradnja infrastrukturnog sustava s uređajem za pročišćavanje otpadnih voda u naselju Kneževi Vinogradi. Naime, mala naselja imaju posebno nepovoljno stanje izgrađenosti komunalne infrastrukture, što naglašava potrebu primjene mjera zaštite izvorišta vode za piće, bilo uvođenjem odgovarajućeg režima korištenja prostora u zonama sanitarne zaštite i/lil primjenom tehnološko-ekonomski zahtjevnijih postupaka kondicioniranja voda. Poboljšanje, očuvanje i zaštita voda proizlaze i iz međunarodnih obveza Republike Hrvatske, odnosno potpisivanjem konvencija i protokola o zaštiti voda i dvostranih ugovora o vodnogospodarskoj suradnji sa susjednim zemljama. Potpisnice međunarodne Konvencije o zaštiti i uporabi prekograničnih vodotoka i međunarodnih jezera, dakle i Republika Hrvatska, obvezale su se da će poduzeti sve potrebne mjere za sprječavanje, nadzor i smanjenje prekograničnih posljedica ispuštanja štetnih tvari.

U radu se opisuje pristup upravljanju projektom izgradnje UPOV-a u Kneževim Vinogradima koji predstavlja složen, dinamički sustav, uvjetovan okruženjem u kojem djeluje, a koji je usmjeren prema postizanju specifičnog cilja, odnosno postizanju propisanih parametara kvalitete otpadne vode. Osnovna karakteristika svakog UPOV-a je da sve elemente treba podrediti u hidrauličkom i tehnološkom smislu u jednu cjelinu, uz što manje troškove investiranja. Pristup izgradnji UPOV-a u Kneževim Vinogradima odvijao se kroz tri faze: koncipiranje, definiranje i izvođenje.

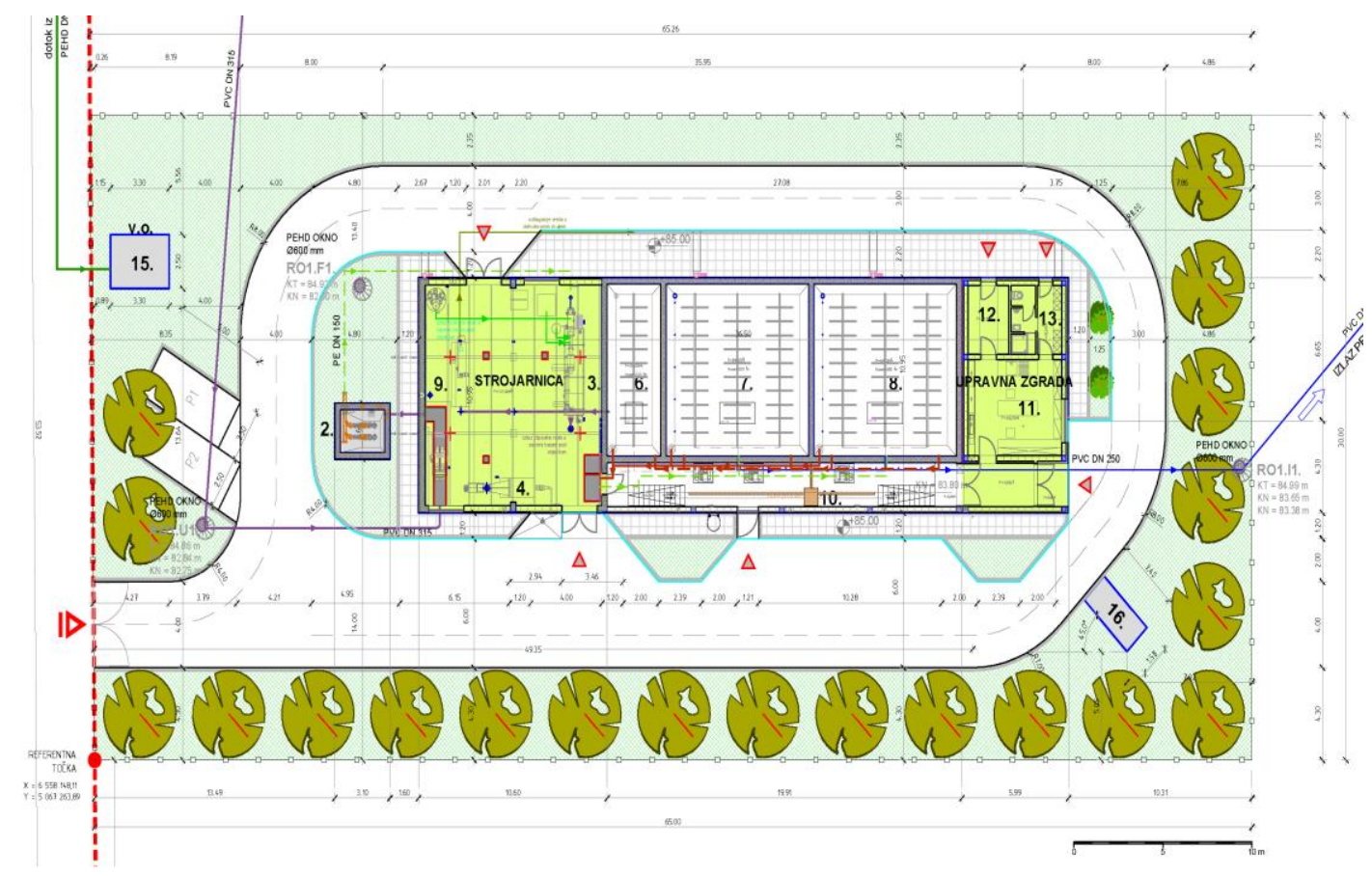

\section{Slika 1 - Situacija mikrolokacije uređaja za pročišćavanje otpadnih voda (izvor: Hidroing Osijek) [9]}

Sustav financiranja komunalne infrastrukture provodi se sredstvima proračuna gradova i općina koji su iste dužne i održavati. Gradovi i općine mogu komunalnim trgovačkim društvima povjeriti ovu djelatnost na isti način kao i javnu vodoopskrbu i javnu odvodnju. Županije supsidijarno donose odluku o zaštiti izvorišta te mogu biti osnivači isporučitelja vodne usluge javne vodoopskrbe koji isporučuje vodu drugim isporučiteljima vodnih usluga. $\mathrm{U}$ okviru navedenog sustava, županije mogu donijeti odluku o naknadi za razvoj sukladno Zakonu o financiranju vodnoga gospodarstva. 
Komunalno poduzeće Baranjski vodovod d.o.o. iz Belog Manastira, zaduženo za održavanje komunalne infrastrukture u Kneževim Vinogradima, i Hrvatske vode d.d., raspisale su natječaj za projektiranje i izgradnju uređaja za pročišćavanje otpadnih voda (UPOV) kapaciteta 2500 ES na lokaciji Kneževi Vinogradi. Navedena veličina uređaja za pročišćavanje otpadnih voda pripada skupini manjih uređaja čija površina iznosi $1511 \mathrm{~m}^{2}$. Unutar kompleksa uređaja izgrađena je građevina dimenzija 36,35x10,85 m i crpna stanica dimenzija 3,1×2,6 m (slika 1). Izvedeni su cjevovodi nužni za funkciju postrojenja za pročišćavanje te precrpno postrojenje za podizanje otpadne vode na tehnološki željenu razinu. Trasa ispusta i izljeva pročišćenih voda u kanal Kenca prolazi građevinskim i poljoprivrednim zemljištem. UPOV u Kneževim Vinogradima izgrađen je polovicom 2012. godine i u tijeku je probni rad radi dokazivanja tehnološke funkcionalnosti rada.

\section{Pročišćavanje otpadnih voda „SBR“ postupkom}

SBR postupak (Sequenzing Batch Reaktor) označava intervalni reaktorski princip pročišćavanja otpadnih voda potpunim biološkim procesom pomoću aktivnog mulja. Osnovna karakteristika svakog biološkog postupka pročišćavanja otpadnih voda sa aktivnim muljem je miješanje ulazne otpadne vode $s$ aktivnim muljem uz periodično ili kontinuirano unošenje kisika iz zraka procesom ozračivanja (slika 2).

Otpadna voda se pročišćava pomoću mikroorganizama koji organsko onečišćenje pretvaraju u taloživu biomasu (aktivni mulj), odnosno u hlapive neškodljive plinovite spojeve koji odlaze u atmosferu.

Mješavina obrađene otpadne vode i biomase nakon bioaeracijskih postupaka podliježe postupku smirivanja, taloženja i odvajanja tekuće od krute faze. Tekuća faza je pročišćena voda koja se slobodno ispušta u prijamnik, dok se kruta faza ili aktivni mulj vraća u recirkulacijskom procesu u biološki stupanj pročišćavanja. Manji dio mulja se izdvaja i obrađuje u postupku obrade mulja.

Prednosti ovog postupka su visoki učinak pročišćavanja vode, veliki raspon mogućih opterećenja, visoka pogonska sigurnost i jednostavno vođenje postupka. Odgovarajućim dimenzioniranjem i oblikovanjem uređaja za pročišćavanje, moguće je savladati povremena vršna opterećenja bez bitnih utjecaja na stupanj pročišćavanja.
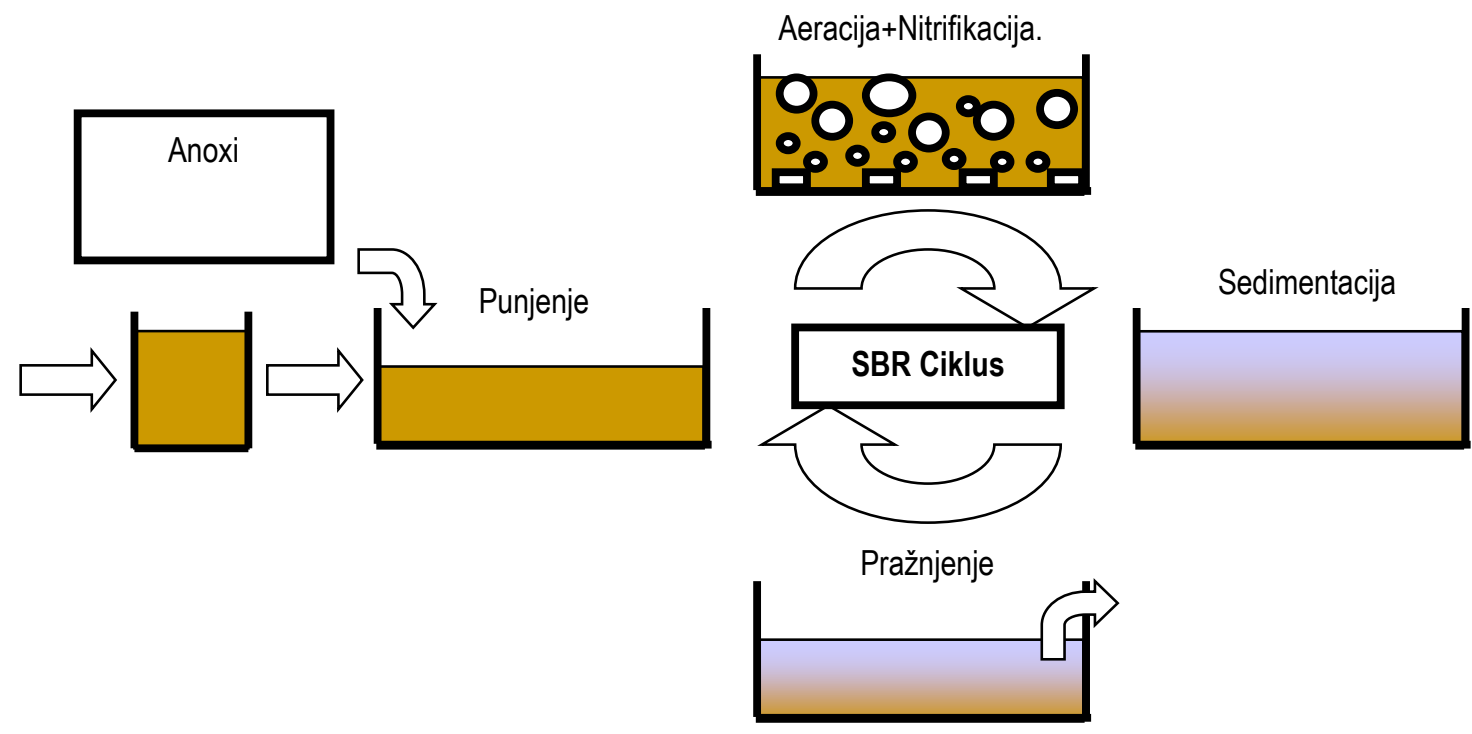

Slika 2 - Tehnološka shema faza ciklusa u SBR-uređaju (izvor: Hidroing Osijek) [9]

Anoksična zona (ANOXI) predstavlja područje osiromašeno kisikom, odnosno područje u kojem se odvija proces denitrifikacije (oslobađanje dušika iz nitritnih i nitratnih spojeva) ili nitrifikacije (pretvaranje amonijaka i amonijevih soli u nitrite i nitrate), ovisno o parametrima koji se žele postići. Bakterije za prehranjivanje umjesto kisika koriste nitrate. Nitrati u anoksičnog zoni se pretvaraju u dušikov plin i u obliku mjehurića ispuštaju se u atmosferu. 


\section{Tehničko-tehnološki opis objekata uređaja za pročišćavanje otpadne vode}

Strukturu uređaja za pročišćavanje čine komponente i elementi zajedničkog uređaja za pročišćavanje otpadnih voda za koji su dane tehničke karakteristike svakog elementa, odnosno objekta. Elementi UPOV-a (slika 3):

\section{Zgrada UPOV-a}

1.1 Dio zgrade za mehaničko pročišćavanje otpadnih voda i dehidraciju mulja

1.1.1 Gruba rešetka

1.1.2 Kombinirani uređaj: automatsko sito i aerirani pjeskolov i mastolov

1.1.3 Stanica za prihvat sadržaja septičkih jama

1.1.4 Jedan sabirni bazen ispod objekta UPOV-a

1.1.5 Mjerač protoke

1.1.6 Dozirna stanica polielektrolita

1.1.7 Strojna dehidracija

1.1.8 Uređaj za pakiranje mulja u vreće

1.2 Dio zgrade za biološko pročišćavanje otpadnih voda

1.2.1 SBR bazeni

1.2.2 Kompresori (puhala)

1.2.3 Bazen za stabilizaciju

1.2.4 Izlazno kontrolno okno

1.3 Upravni dio zgrade za smještaj upravljačkog sustava, laboratorij i garderobe

1.3.1 Upravni dio zgrade

1.3.2 Trafostanica, elektro-oprema i MSR-tehnika

2 Ulazna crpna stanica

3 Uređenje lokacije s kompletnom infrastrukturom

3.1 Vodoopskrbna mreža na lokaciji UPOV-a

3.2 Sanitarno-fekalna kanalizacijska mreža na lokaciji UPOV-a

3.3 Pristupne parkirališne površine

3.4 Infrastrukturno uređenje lokacije

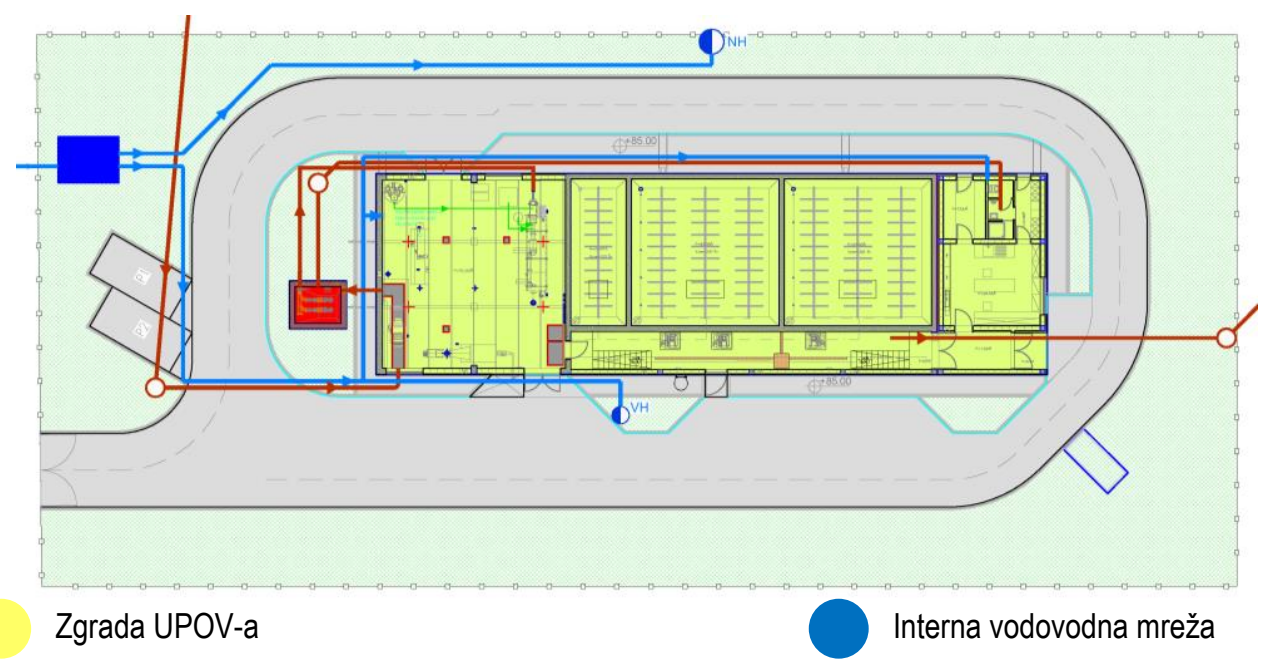

Crpna stanica

Pristupne parkirališne površine

Interna kanalizacijska mreža

Uređenje lokacije

Slika 3 - Grafički prikaz strukturne podjele objekata na lokaciji UPOV-a (izvor: Hidroing Osijek) 


\subsection{Zgrada UPOV-a}

Građevina je sastavljena u tri volumenske forme (slika 4):

- $\quad$ zapadni volumen - planiran za mehaničko pročišćavanje otpadnih voda i dehidraciju mulja

- istočni volumen - predviđen za smještaj upravljačkog sustava, laboratorij i garderobe povremene posade uređaja

- $\quad$ središnji volumen - najmanje visine - namijenjen za smještaj procesnih bazena potrebnih za biološko pročišćavanje otpadne vode koji su povezani hodnikom.

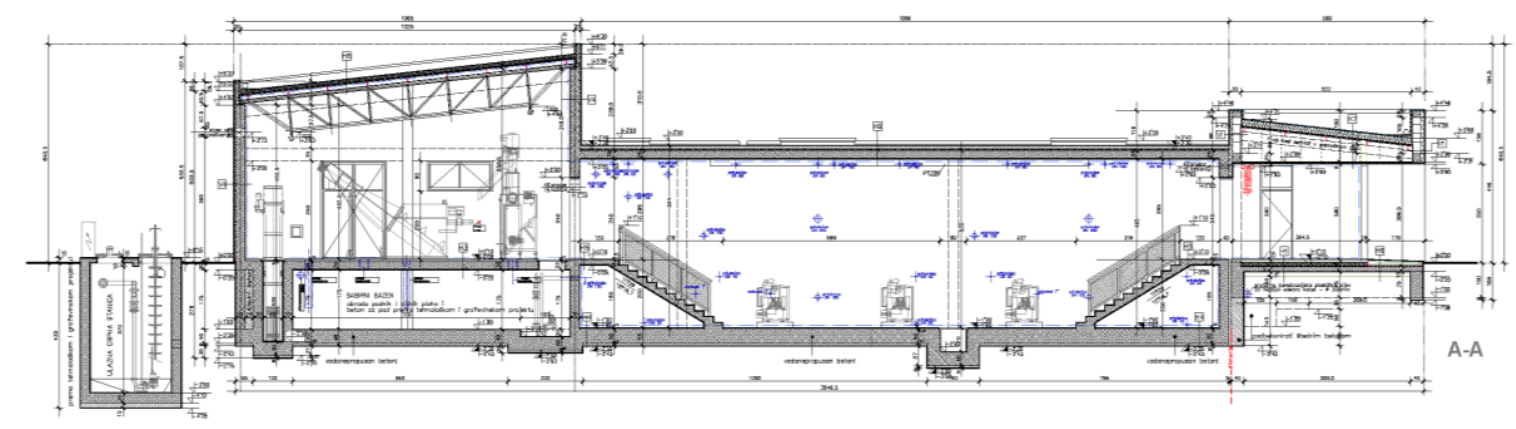

Slika 4 - Karakteristični uzdužni presjek kroz zgradu i crpnu stanicu UPOV-a (izvor: Hidroing Osijek) [9]

\subsection{Ulazna crpna stanica}

Radi osiguranja pravilnog, sigurnog i nesmetanog rada uređaja, potrebno je ulazne otpadne vode dići za cca $4 \mathrm{~m}$. Predviđene su uronjene crpke za konačne kapacitete uređaja te maksimalnog satnog dotoka, a smještene su u sabirnom bazenu. Uključivanje crpki u rad obavljat će se automatski, ovisno o nivou vode u oknu.

\subsection{Uređenje lokacije s kompletnom infrastrukturom}

Potrebno je predvidjeti interni vodovod koji obuhvaća cjevovode tehnološke, pitke i protupožarne vode na uređaju. Interni vodovod mora sadržavati vodomjerno okno propisanih dimenzija. Predviđa se izgradnja kompletne interne kanalizacije između pojedinih objekata, kao i interna kanalizacija oborinskih voda.

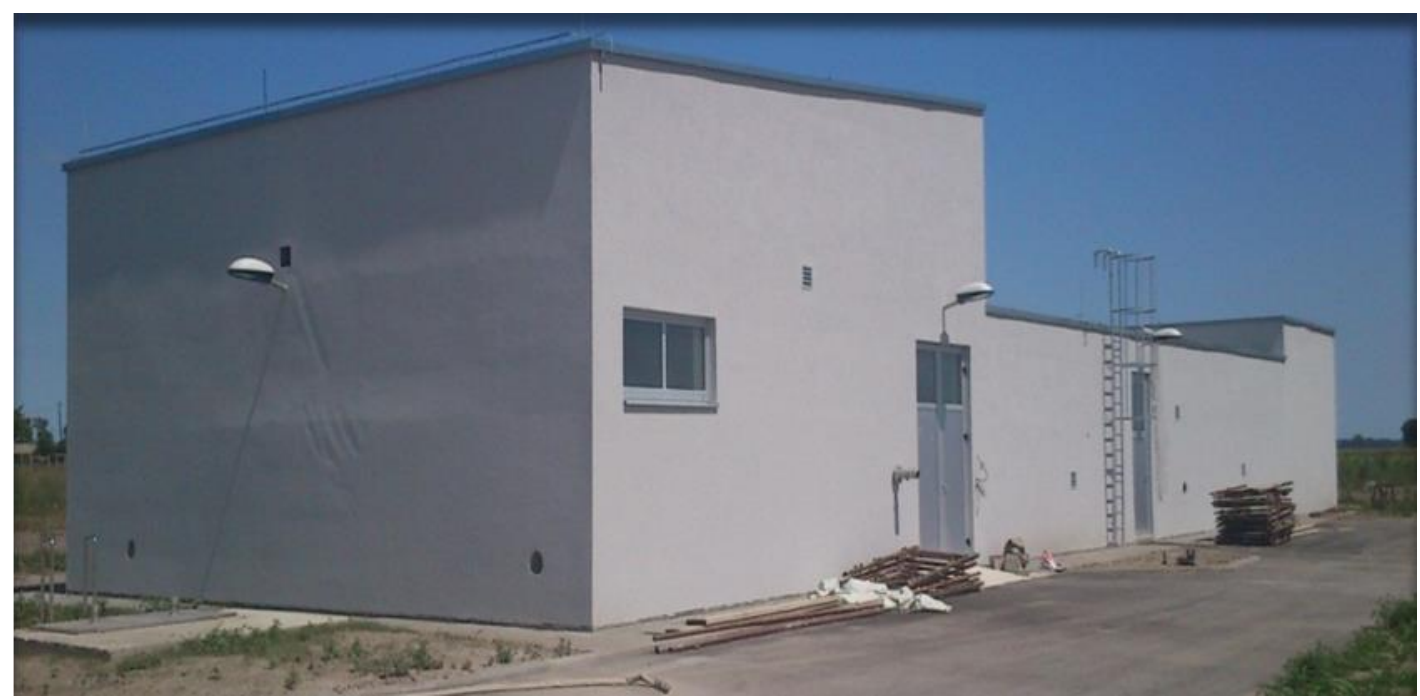

Slika 5 - Pogled na izgrađenu zgradu UPOV-a Kneževi Vinogradi 


\section{Program kontrole tehnološke funkcionalnosti UPOV-a}

U cilju optimalizacije procesa pročišćavanja otpadnih voda, kontrole funkcionalnosti uređaja, odnosno dokazivanja kvalitete pročišćene vode, kao i potvrde projektirane i izvedene tehnologije prethodnog čišćenja otpadnih voda, provesti će se mjere nadzora kakvoće rada kao i učinkovitosti uređaja za pročisćavanje otpadnih voda - UPOV Kneževi Vinogradi. U tu svrhu planira se i određuje obavljanje probnog rada uređaja za pročišćavanje otpadnih voda.

Navedene mjere nadzora i utvrđivanja kvalitete pročišćene otpadne vode sukladne su Vodopravnim uvjetima, izdanima od strane Hrvatskih voda, Vodnogospodarskog odjela za vodno područje sliva Drave i Dunava u Osijeku. Početak probnog rada bit će nakon završene izgradnje svih objekata uređaja, kao i montaže elektrostrojarske opreme uređaja.

Trajanje cjelokupnog probnog rada iznosi 6 (šest) mjeseci neprekidnog rada uređaja.

Nakon završetka probnog rada uređaja investitor će dokaze o ispravnom i funkcionalnom radu uređaja, kao i dokaze o kvaliteti pročišćenih voda, dokumentirati završnim elaboratom te analizama obavljenih ispitivanja po ovlaštenom laboratoriju, a koje mora izraditi projektant ili ovlaštena tvrtka.

\section{$5 \quad$ Povezivanje vremena i troškova u projektu}

Povezivanje vremena i troškova u projektu prikazano je financijskim planom praćenja troškova u vremenu za fazu izvođenja radova:

- Tablica planiranih troškova (financijski plan) za izradu tender dokumentacije - tablica je napravljena na osnovi planiranih troškova iz tender dokumentacije kojom se izvođač prijavio na natječaj;

- Tablica realiziranih troškova (izvedeni radovi) - tablica se ispunjava nakon faze razrade projektne dokumentacije, odnosno nakon izrade glavnog projekta.

Produkt ovih dviju tablica je grafički prikaz troškova u vremenu "S - krivulja" na kojem se jednostavno prate planirani i realizirani troškovi. Ako dolazi do većih odstupanja od planiranog, vizualno se lako uočavaju i pravovremeno se može reagirati i poduzeti korektivne mjere.

Grafički prikaz kumulativnih troškova u vremenu "S" - krivulja prikazan je za Uređaj za pročišćavanje otpadnih voda u Kneževim Vinogradima na kojemj se mogu jednostavno pratiti planirani i realizirani troškovi tijekom faze izgradnje. Praćenje troškova u vremenu za projekt Uređaja za pročišćavanje otpadnih voda u Kneževim Vinogradima veoma je bitno zbog planiranja sredstava za buduća razdoblja u službi investitora, dok izvođaču pokazuje koliku je realizaciju postigao i koliki priljev novčanih sredstava može očekivati. Ako se pokaže da je realizacija podbacila, moraju se poduzeti korektivne mjere (npr. povećanje radne snage, radnih sati, strojeva, uvođenje dvije smjene itd.).

\subsection{Strukturna podjela elemenata (WBS) UPOV-a Kneževi Vinogradi}

Strukturna podjela elemenata UPOV-a Kneževi Vinogradi je objektno orijentirana na elemente koji čine UPOV, a to su: zgrada UPOV-a, crpna stanica, uređenje lokacije s kompletnom infrastrukturom (pristupne parkirališne površine, vodoopskrba i vatroobrana na lokaciji UPOV-a, kanalizacijska mreža, uređenje okoliša) (slika 6). 


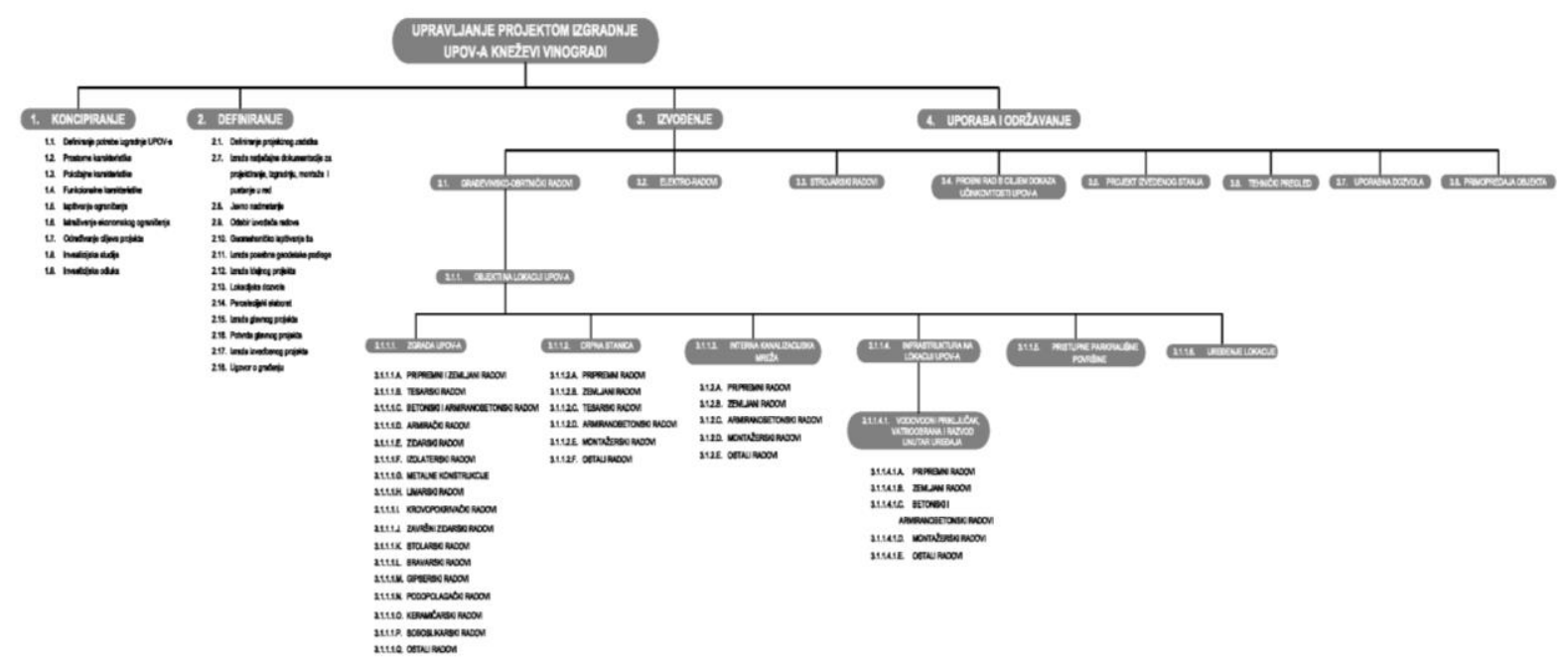

Slika 6 - Strukturna podjela UPOV-a Kneževi Vinogradi

\subsection{Gantogram za projekt „UPOV Kneževi Vinogradi“}

Vrijeme trajanja aktivnosti uneseno je u terminskom planu (gantogramu) koji je napravljen za sve faze upravljanja projektom (koncipiranje, definiranje, izvođenje i korištenje) (slika 7).

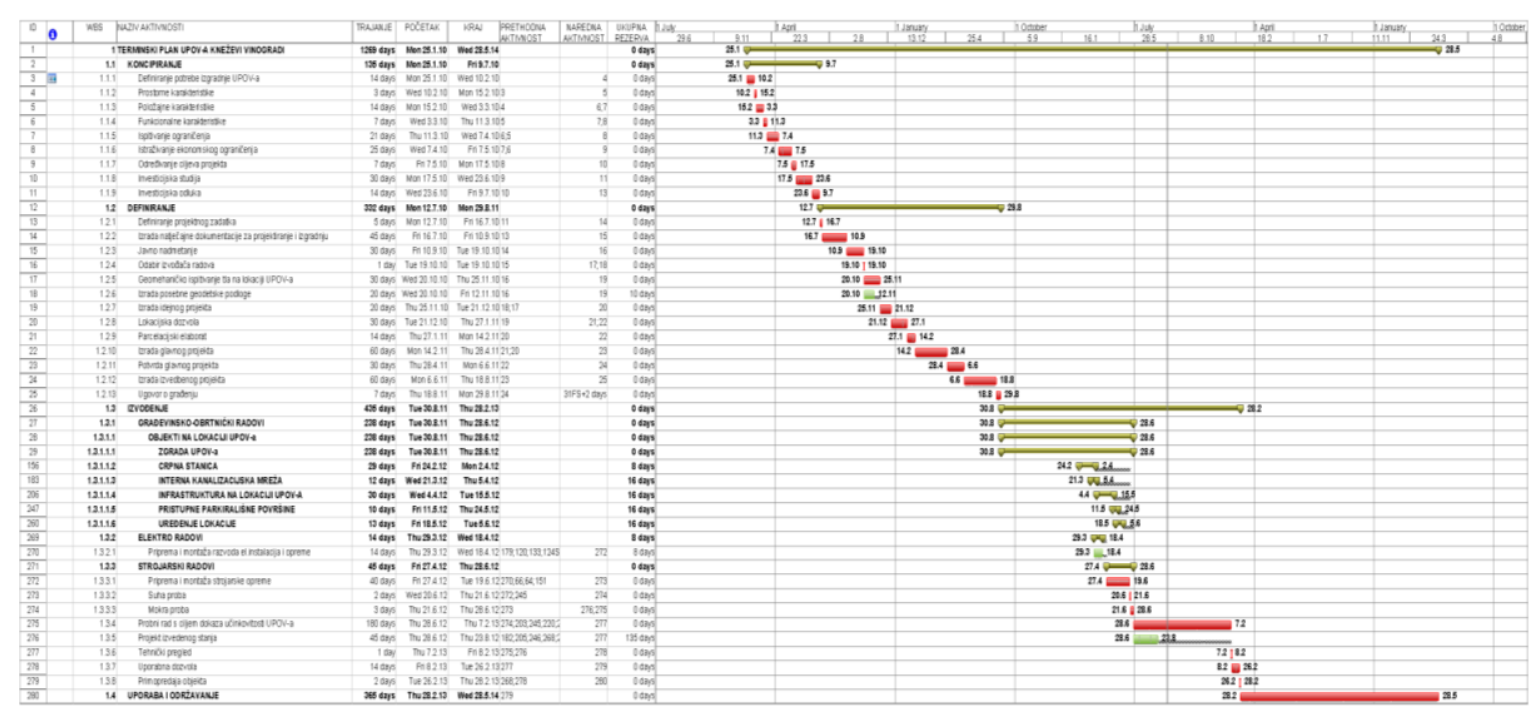

Slika 7 - Gantogram UPOV- a Kneževi Vinogradi

\subsection{Mrežni plan za projekt „UPOV Kneževi Vinogradi“}

Mrežni plan je tehnika linijskog planiranja u kojemu su sve aktivnosti vremenski povezane. Faza koncipiranja i definiranja je grubo razrađena, dok je faza izvođenja detaljno razrađena i sadrži oko 250 aktivnosti koje su tamo gdje je planirana odgoda međusobno povezana vremenskim vezama (FS - kraj početak, SS - početak-početak, FF kraj-kraj) (slika 8). Faza korištenja unesena je u razdoblju od samo jedne godine zbog ograničenog ispisa na papir, inače predviđeno razdoblje korištenja objekta je oko 30 godina. 


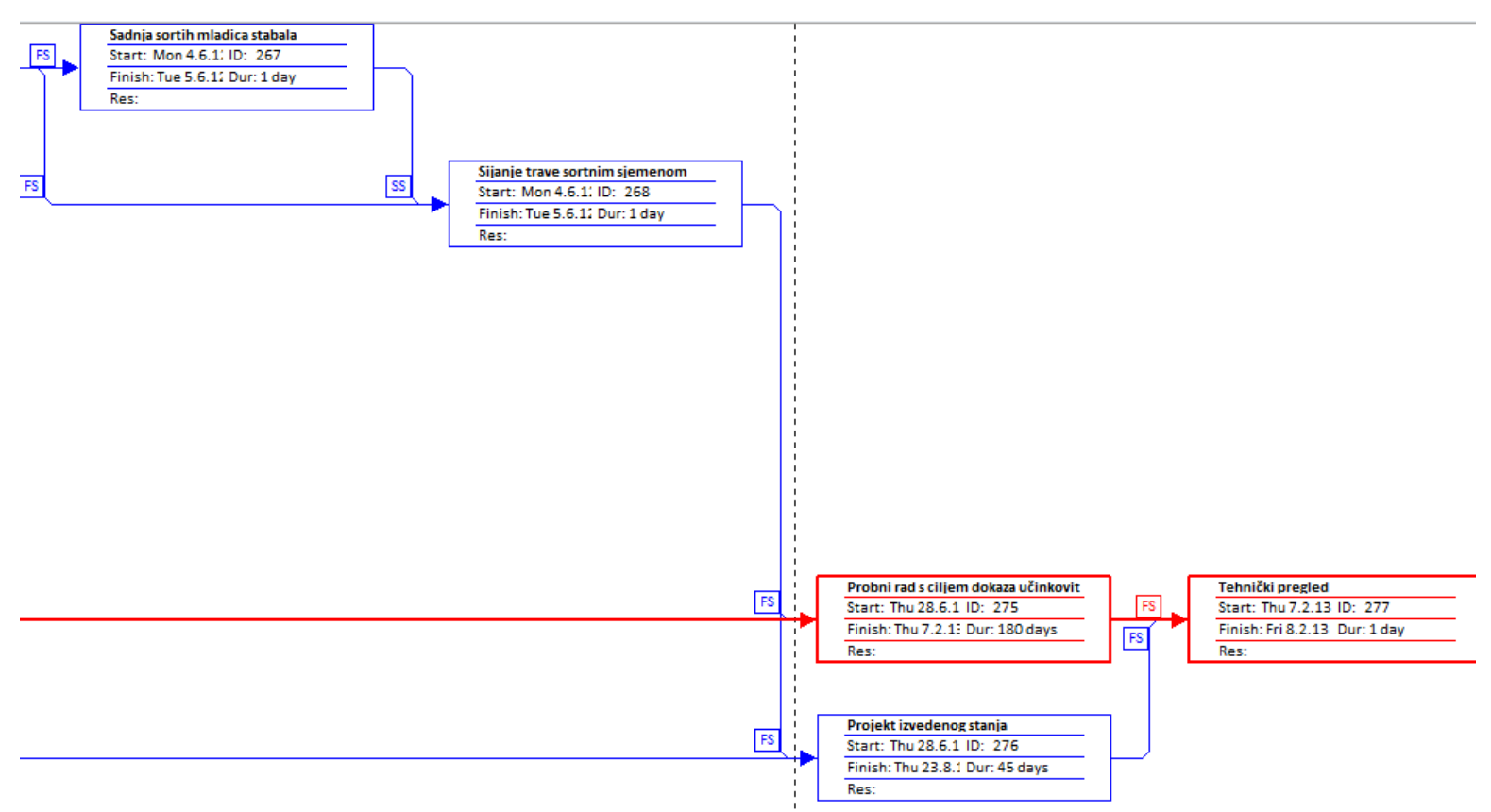

Slika 8 - Dio mrežnog plana UPOV- a Kneževi Vinogradi

\subsection{Financijski plan za tender dokumentaciju projekta „UPOV Kneževi Vinogradi“}

Financijski plan je napravljen na osnovi planiranih troškova iz tender dokumentacije kojom se izvođač prijavio na natječaj. Na dnu tablice 1 nalazi se kumulativna vrijednost troškova po mjesecima. Ovaj financijski plan je napravljen za razdoblje dok je trajala izgradnja objekta (od kolovoza 2011. godine do lipnja 2012. godine).

\section{Tablica 1 - Financijski plan za UPOV Kneževi Vinogradi}

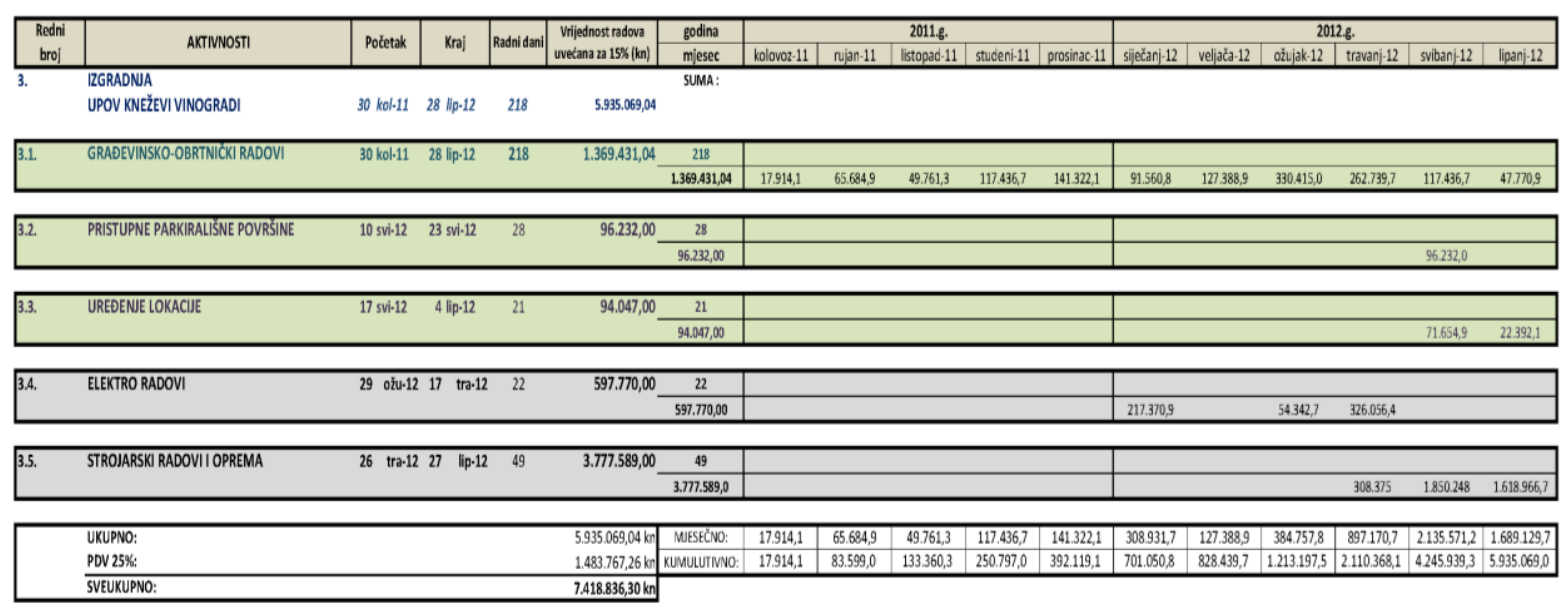

\subsection{Tablica realiziranih troškova za projekt „UPOV Kneževi Vinogradi“}

Tablica realiziranih troškova ispunjava se nakon faze razrade projektne dokumentacije, odnosno nakon izrade glavnog projekta. Tablica je konstruirana tako da se upisivanjem trajanja pojedinih aktivnosti (dan ili mjesec ili godina) automatski mijenjaju planirani troškovi za uneseno razdoblje. Kao dodatna mogućnost napravljen je i prikaz trajanja aktivnosti, odnosno prikazani broj radnih dana za pojedine faze radova (tablica 2). Na dnu tablice 
nalazi se kumulativna vrijednost troškova po mjesecima. Ovaj financijski plan je napravljen za razdoblje dok je trajala izgradnja objekta (od kolovoza 2011. do lipnja 2012.).

\section{Tablica 2 - Tablica realiziranih troškova za UPOV Kneževi Vinogradi}

\begin{tabular}{|c|c|c|c|c|c|c|c|c|c|c|c|c|c|}
\hline \multirow{2}{*}{\begin{tabular}{|c|c|} 
Redni \\
broj \\
\end{tabular}} & \multirow{2}{*}{ AKTIUNoSTI } & \multirow{2}{*}{ Poctetak } & \multirow{2}{*}{ Kraj } & \multirow{2}{*}{ Radrid dani } & \multirow{2}{*}{ 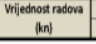 } & \multirow{2}{*}{$\begin{array}{l}\text { godina } \\
\text { miessec } \\
\end{array}$} & \multicolumn{4}{|c|}{2011.8.} & \multicolumn{3}{|r|}{2012.8.} \\
\hline & & & & & & & \begin{tabular}{l|l} 
kelovor:-11 & rujan:-11 \\
\end{tabular} & listopad -11 & studen:-11 & prosinacc-11 & sijecan: 12 & veluáa-12 & 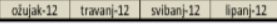 \\
\hline \multirow[t]{2}{*}{31.1 .1 .13}$. & C. Betonski i armiranobetonski radowi & 12 njp11 & 21 oiv-12 & 52 & $933.086,00$ & 52 & 7 & 9 & 16 & 9 & 4 & 5 & 2 \\
\hline & & & & & & $933.086,00$ & $125.607,7$ & 16L.1995, 7 & 287.103 & $161.495,7$ & $7.775,8$ & $89.79,8$ & $35.87,9$ \\
\hline 3.1.1.13.1. & Betoniranje podbinogog betona & $12 \mathrm{tuj}-11$ & $14 \mathrm{ruv}-11$ & 3 & & & 3 & & & & & & \\
\hline 31.1.1.3.2. & 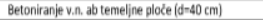 & 21 rij 11 & 26 ruj-11 & 4 & & & 4 & & & & & & \\
\hline 3.1.1.13.3. & Betonitanie v.,. ab a zidova & 12 16s-11 & $24 \mid 5 ; \cdot 11$ & 9 & & & & 9 & & & & & \\
\hline 3.1.1.13.4. & Betoniranje v.n. ab plocé iznad sabirnog bazena ibaz & 11 stu-11 & 21 stu-11 & 7 & & & & & 7 & & & & \\
\hline 3.1.1.1.3.5. & Betoniranie ab stupova & 14 pro- -11 & 19 pro-11 & 4 & & & & & & 4 & & & \\
\hline 3.1.1.1.13.6. & Betoniranje ab nadvoja, horiz. ivertik. serklazaz & 16 pro-11 & 20 pro-11 & 3 & & & & & & 3 & & & \\
\hline 3.1.1.1.3.7. & Betoniranje ab freda & 29 pro-11 & $25 \mathrm{si}-12$ & 3 & & & & & & 2 & 1 & & \\
\hline 3.1.1.13.8. & Betoniranje monta stropa & 11 sil 12 & 13 sij-12 & 3 & & & & & & & 3 & & \\
\hline 3.1.1.13.9. & 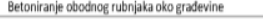 & $13 v \mid \cdot 12$ & 14 (1)|-12 3 & 2 & & & & & & & & 2 & \\
\hline 3.1.1.13.1.10. & Betoniranje betona za pad na krovu gradevine & $27 \mathrm{vil}-12$ & $29 \mathrm{vil}-12$ & 3 & & & & & & & & 3 & \\
\hline 3.1.1.13.11. & Betoniranie nivelirajucteg sloja podne konstrukcije & 20 ofu-12 & 21 ozuv-12 & 2 & & & & & & & & & 2 \\
\hline 3.1.1.13.12. & - Betonitanj| ab trakatith temelja & 8 stu-11 & 9 stu-11 & 2 & & & & & 2 & & & & \\
\hline 3.1.1.13.13. & Betoniranje ab podne ploče $(d=15 \mathrm{~cm})$ & 15 stu-11 & 15 stu-11 & 1 & & & & & 1 & & & & \\
\hline 3.1.1.13.14. & Betoniranie stubitla u prostor komunikacie & 14 stu-11 & 15 stu-11 & 2 & & & & & 2 & & & & \\
\hline 3.1.1.1.3.15. & Betoniranje betonskih postamenata uredsaja i oprem & 28 stu-11 & 29 stu-11 & 2 & & & & & 2 & & & & \\
\hline 3.1.1.13.1.6. & Betoniranje betona a padu processim bazenima & 28 stu-11 & 29 stu-11 & 2 & & & & & 2 & & & & \\
\hline \multirow[t]{2}{*}{3.1 .1 .14} & D. Armiracki radovi & 19 ruj11 & $8 \mathrm{vil}+12$ & 32 & $104.000,00$ & 32 & 4 & 3 & 12 & 9 & & 4 & \\
\hline & & & & & & $104.000,00$ & $13.000,0$ & $9.750,0$ & 39.000 & $29.250,0$ & & $13.000,0$ & \\
\hline 3.1.1.14.1. & Ugradnia armature a temelinu ploču & $19 \mathrm{ruj}-11$ & 21 ruj-11 & 3 & & & 3 & & & & & & \\
\hline 3.1 .1 .14 .2$. & Upradnia armature za ab zidove & $30 \mathrm{tut}-11$ & 5 lis:11 & 4 & & & 1 & 3 & & & & & \\
\hline 3.1.1.14.3. & 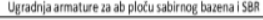 & $9 s \mathrm{su}-11$ & 11 stu-11 & 3 & & & & & 3 & & & & \\
\hline 3.1.1.14.4. & Ugradnia armature ta ab stupove & 8 pro-11 & 12 pro-11 & 3 & & & & & & 3 & & & \\
\hline 3.1.1.14.5. & Ugradnia a rmature za serkkajete & 8 pro-11 & 12 pro-11 & 3 & & & & & & 3 & & & \\
\hline 3.1.1.14.6. & Ugradnia a rmature $a$ a ab grede & 27 pro-11 & 29 pro-11 & 3 & & & & & & 3 & & & \\
\hline 3.1.1.14.7. & Ugradnia armature za obodni rubniak oko gradevine & $3 v|\cdot| 12$ & $8 \mathrm{vul} \cdot 12$ & 4 & & & & & & & & 4 & \\
\hline 3.1.1.14.8. & Ugradnja armature za trakastet temelije & 7 stu-11 & 8 stu-11 & 2 & & & & & 2 & & & & \\
\hline 3.1.1.1.4.9. & Upradnja armature a padnu ploču & 14 stu-11 & 15 stu-11 & 2 & & & & & 2 & & & & \\
\hline 3.1.1.14.1.10. & Ugradnia armature za stubšste & 9 stu-11 & 14 stu-11 & 4 & & & & & 4 & & & & \\
\hline 3.1.1.1.1.11. & Upradnja armature a betonske postamente & 28 stu-11 & 28 stu-11 & 1 & & & & & 1 & & & & \\
\hline \multirow[t]{2}{*}{ 3.1.1.1.5. } & E. Zdarski radoví & 28 stu-11 & 10 sij-12 & 14 & $57,800,00$ & 14 & & & 4 & $\frac{6}{6}$ & $\overline{4}$ & & \\
\hline & & & & & & $57,800,00$ & & & 16.5443 & $24,71,4$ & 165143 & & \\
\hline 3.1.1.15.1. & 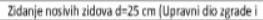 & 28 stu-11 & 2 pro-11 & 6 & & & & & 4 & 2 & & & \\
\hline 3.1.1.1.5.2. & 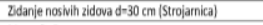 & 8 pro-11 & 13 pro-11 & 4 & & & & & & 4 & & & \\
\hline 3.1.1.15.3. & Montáa Fert stropa & 5 sili 12 & 10 sij:12 2 & 4 & & & & & & & 4 & & \\
\hline
\end{tabular}

\subsection{Krivulja troškova „cash flow (S - krivulja)“ za projekt „UPOV Kneževi Vinogradi“}

S - krivulja predstavlja tehniku dinamičkog planiranja pomoću koje je usporedno moguće prikazati planirano stanje, trenutačno stanje i prognozu budućeg stanja projekta, te se zbog tih karakteristika često koristi i u metodama kontrole i upravljanja projektom, posebice u metodi EVA [1, 5]. S - krivulja nastaje kao produkt tablice planiranih i realiziranih troškova (slika 9).

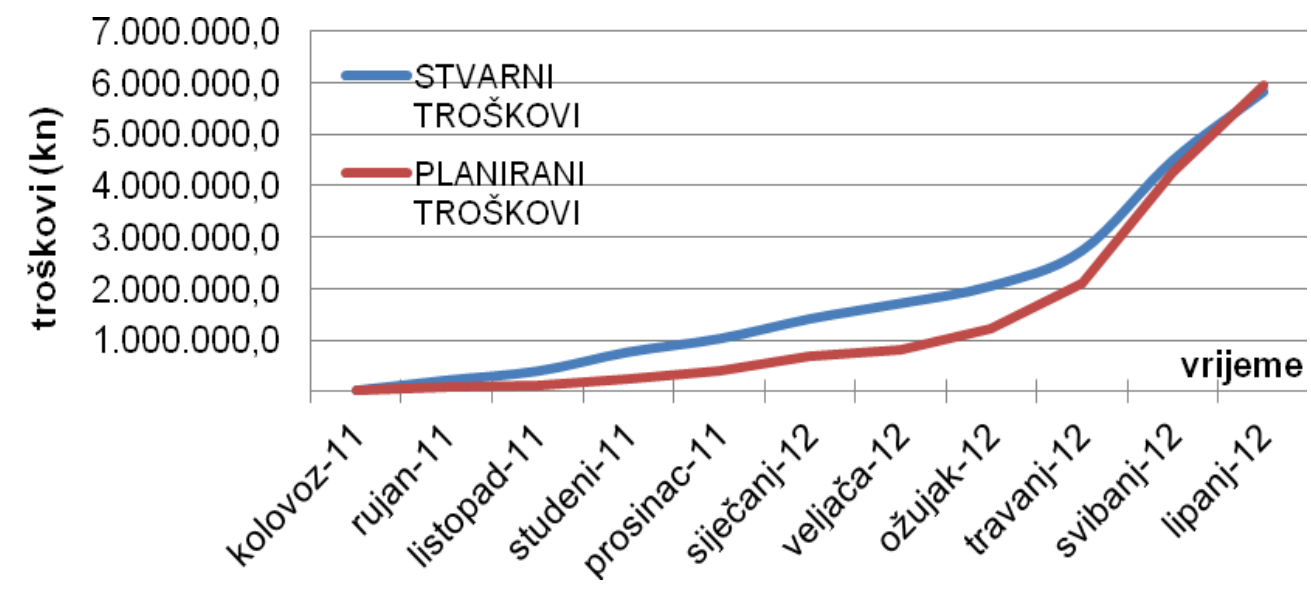

Slika 9 - Grafički prikaz planiranih i realiziranih troškova (S - krivulja) za UPOV Kneževi Vinogradi 


\subsection{Tablični i grafički prikaz vremenskog odnosa među fazama projekta za projekt „UPOV Kneževi Vinogradi“"}

Općeniti proces trajanja aktivnosti (prema fazama projekta) je dugotrajan proces i u većini slučajeva najveći utrošak vremena otpada na fazu koncipiranja i definiranja projekta, a najmanji na fazu izvođenja projekta (tablica 3). Kriteriji koji određuju trajanje su složenost, veličina projekta, administracija, organizacijski menadžment itd. Iz navedenog grafičkog prikaza vidljivo je da proces trajanja aktivnosti prema fazama projekta raste linearno prema kronološkom redoslijedu i da je proces dugotrajan, iako se radi o „malom" projektu. Iz ovoga se može zaključiti da je organizacijska struktura najvažniji čimbenik, jer se njime utječe direktno na trajanje, pri čemu dobivamo linearnu krivulju trajanja aktivnosti.

Tablica 3 - Tablični prikaz vremenskog odnosa među fazama projekta

\begin{tabular}{|c|l|c|c|c|}
\hline WBS & Faza & Trajanje (dani) & Udio u trajanju & $\begin{array}{l}\text { Kumulativno } \\
\text { trajanje (dani) }\end{array}$ \\
\hline 1. & KONCIPIRANJE & 181 & $20,45 \%$ & $20,45 \%$ \\
\hline 2. & DEFINIRANJE & 269 & $30,40 \%$ & $50,85 \%$ \\
\hline 3. & IZVOĐENJE & 435 & $49,15 \%$ & $100,00 \%$ \\
\hline \multicolumn{2}{|l|}{ Ukupno: } & $\mathbf{8 8 5}$ \\
\hline
\end{tabular}

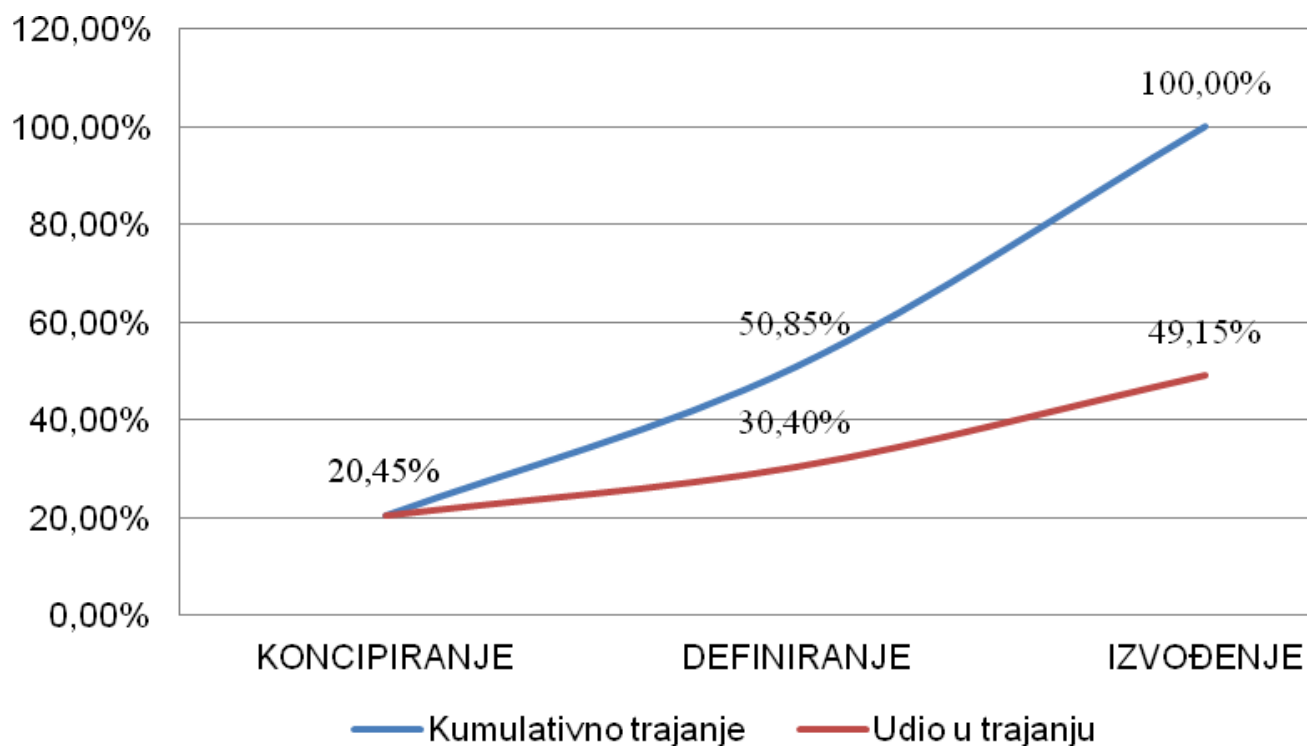

Slika 10 - Grafički prikaz vremenskog odnosa među fazama projekta za UPOV Kneževi Vinogradi

\subsection{Tablični i grafički prikaz planiranih i realiziranih troškova za projekt „UPOV Kneževi Vinogradi"}

U tablici 4 prikazana je usporedba planiranih i realiziranih troškova prema strukturnoj podjeli elemenata UPOV-a Kneževi Vinogradi. Za usporedbu troškova dodana je kolona koja prikazuje razliku odnosa planiranog i realiziranog. Kolona može imati pozitivnu i negativnu vrijednost, gdje pozitivna vrijednost predstavlja profit (zaradu), a negativna vrijednost predstavlja trošak (gubitak). Sljedeća kolona na ilustrativan način prikazuje postotak ostvarenog profita, odnosno troška. 


\section{Tablica 4 - Tablični prikaz planiranih i realiziranih troškova}

\begin{tabular}{|l|r|r|r|r|r|}
\hline Vrsta radova & $\begin{array}{r}\text { Planirani troškovi } \\
\mathbf{( k n )}\end{array}$ & $\begin{array}{c}\text { Realizirani } \\
\text { troškovi (kn) }\end{array}$ & $\begin{array}{l}\text { Razlika (planirano } \\
\text { - realizirano) (kn) }\end{array}$ & $\begin{array}{c}\text { Udio ostvarene } \\
\text { dobiti }\end{array}$ & $\begin{array}{l}\text { Kumulativna } \\
\text { dobit (kn) }\end{array}$ \\
\hline GRAĐEVINSKI RADOVI & $1.369 .431,04$ & $1.975 .747,65$ & $-606.316,61$ & $-10,22 \%$ & $-10,22 \%$ \\
\hline PRISTUPNE PARKIRALIŠNE POVRŠINE & $96.232,00$ & $171.495,05$ & $-75.263,05$ & $-1,27 \%$ & $-11,48 \%$ \\
\hline UREĐENJE LOKACIJE & $94.047,00$ & $85.420,00$ & $8.627,00$ & $0,15 \%$ & $-11,34 \%$ \\
\hline ELEKTRO RADOVI & $597.770,00$ & $620.018,00$ & $-22.248,00$ & $-0,37 \%$ & $-11,71 \%$ \\
\hline STROJARSKI RADOVI I OPREMA: & $3.777 .589,00$ & $2.978 .850,00$ & $798.739,00$ & $13,46 \%$ & $1,74 \%$ \\
\hline Ukupno (kn) : & $\mathbf{5 . 9 3 5 . 0 6 9 , 0 4}$ & $\mathbf{5 . 8 3 1 . 5 3 0 , 7 0}$ & $\mathbf{1 0 3 . 5 3 8 , 3 4}$ & $1,74 \%$ \\
\hline
\end{tabular}

Sumiranjem navedenih vrijednosti u tablici 4 prikazana je konačna vrijednost, što u ovom slučaju predstavlja profit. Ovakav način prikazivanja troškova omogućava izvođaču (investitoru) jasan pregled troškova, $\mathrm{s}$ mogućnošću okvirne orijentacije o podbacivanju procjene vrste radova.

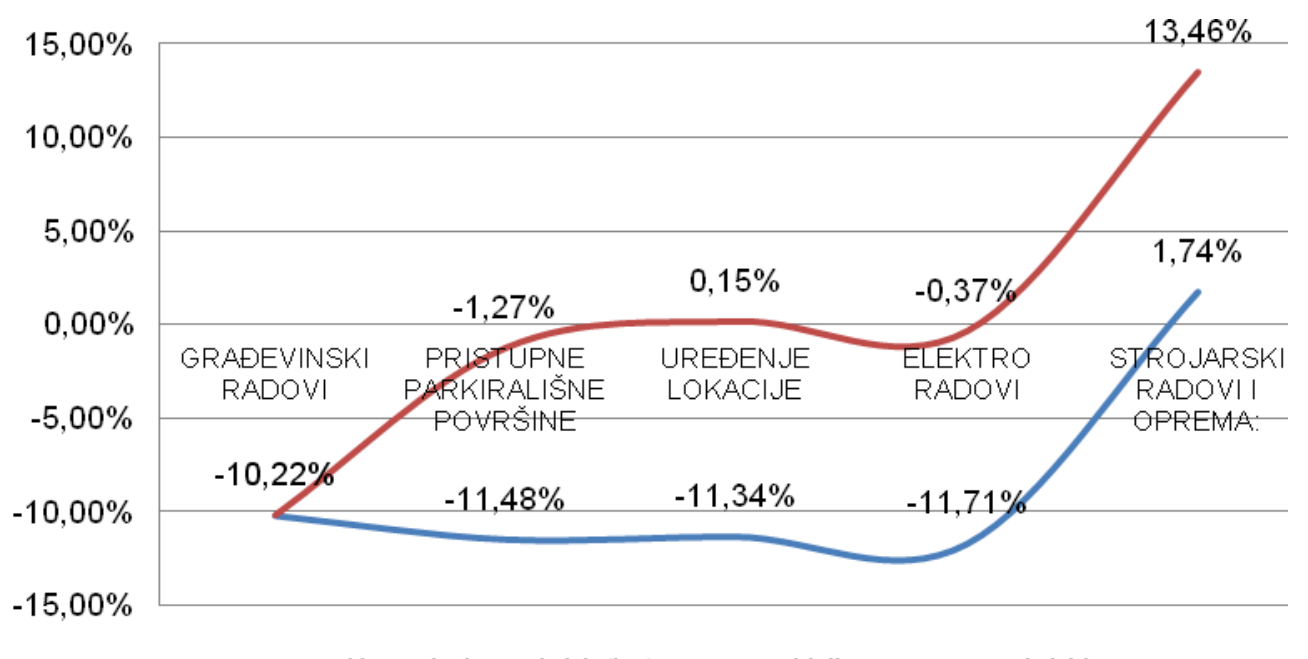

Kumulativna dobit $(\mathrm{kn}) \quad$ Udio ostvarene dobiti

\section{Slika 11 - Grafički prikaz planiranih troškova}

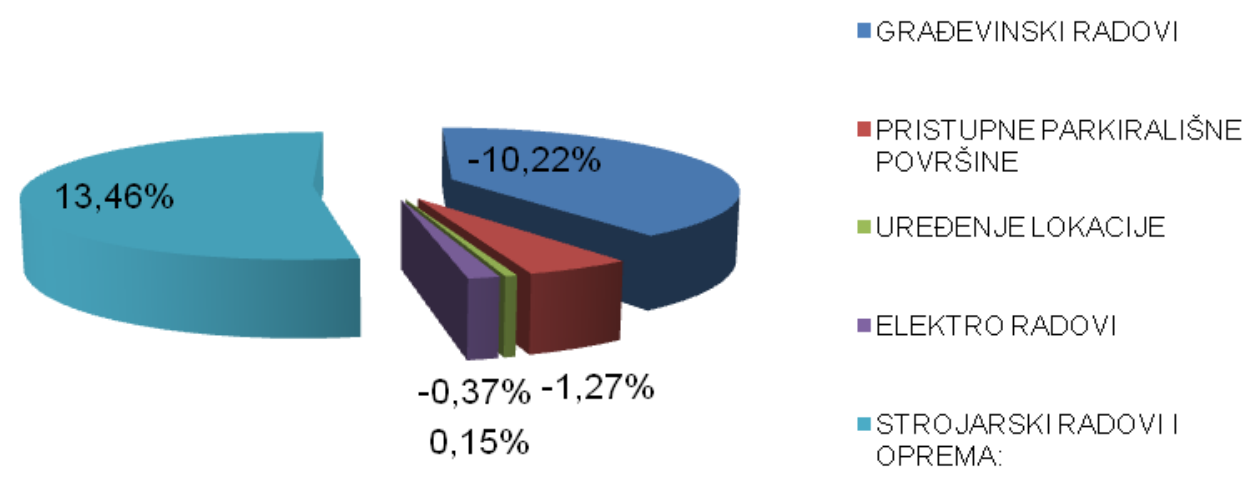

Slika 12 - Grafički prikaz ostvarene dobiti po vrstama radova 


\section{$6 \quad$ Zaključak}

Upravljanje projektom izgradnje uređaja za pročišćavanje otpadnih voda u Kneževim Vinogradima obrađeno je u tri faze projekta (koncipiranje, definiranje i izvođenje). Upravljanje projektom izgradnje obrađeno je teoretski (primjenom literaturnih referenci) i praktično (na temelju iskustva). S obzirom da je uređaj za pročišćavanje otpadnih voda u Kneževim Vinogradima u završnoj fazi izvođenja, naglasak u ovom radu je upravo na navedenoj fazi.

Radi lakšeg praćenja i kontrole, projekt je strukturno (WBS) podijeljen na logične i upravljive dijelove. Svaki dio predstavlja jednu zasebnu cjelinu koja obuhvaća određene vrste radova koji se opet sastoje od aktivnosti. Radi upravljanja, praćenja i kontrole troškova napravljen je financijski plan izvođenja radova (tablica planiranih troškova) i tablica realiziranih troškova. Za izradu tender dokumentacije izvođač je napravio financijski plan, odnosno tablicu planiranih troškova, na osnovi koje je uračunao svoju maržu te dao svoju ponudu za izvođenje radova. Podatci u tablici ne sadrže pojedine važne troškove kao što su: geodetski i geomehanički radovi, usluge projektiranja, probni rad i obuka osoblja, uzorkovanja i mjerenja za vrijeme probnog rada i slično, a koji su od bitnog značenja pri sklapanju ovakve vrste ugovora po sistemu "ključ u ruke“.

$\mathrm{Na}$ osnovi detaljnije razrade projektne dokumentacije napravljena je tablica stvarnih, odnosno realnih troškova izgradnje objekta, a koristi je izvođač radova za kontrolu mjesečne realizacije troškova.

Za fazu izvođenja napravljen je detaljni dinamički i mrežni plan koji prikazuje kompletan tijek izvođenja pojedinih aktivnosti. Svaka promjena nastala tijekom izvođenja se evidentira i ažurira prema dinamici promjena. Svrha svakog investicijskog projekta je biti realiziran u planiranom vremenu, s planiranim sredstvima i propisane kvalitete. Parametri: vrijeme, trošak i kvaliteta predstavljaju osnovu kvalitetnog upravljanja projektom, odnosno omogućuju kontinuirano praćenje pojedinačnih aktivnosti, dijelova projekta i projekta u cjelini.

\section{Literatura}

[1] Čulo, K.: Ekonomika investicijskih projekata, Građevinski fakultet, Osijek, 2011.

[2] Heerkens, R.: Project Management, New York, NY: McGraw-Hill, 2002.

[3] Ispravak Pravilnika o izmjenama i dopunama Pravilnika o graničnim vrijednostima pokazatelja opasnih i drugih tvari u otpadnim vodama, NN 14/01

[4] Kerzner, H.: Project Management. Van Nostrand Reinhold, New York, 1992.

[5] Marenjak, S.: Planiranje i kontrola građenja, Građevinski fakultet Osijek, 2011.

[6] Marić, T.; Radujković, M.; Cerić, A.: Upravljanje troškovima, vremenom i kvalitetom u građevinskim projektima, Građevinar 59, 485-493 (2007.)

[7] PMl; A Guide to the Project Management Body of Knowledge, Third Edition (PMBOK Guide), Project Management Institute, 2004.

[8] Pravilnik o očevidniku zahvaćenih i korištenih količina voda, NN 81/10

[9] Projektna dokumentacija, Uređaj za pročišćavanje otpadnih voda Kneževi Vinogradi 2500 ES, Izvedbeni projekt, Hidroing Osijek, 2011. 